\title{
Isolation and Characterization of Alkaline Pectinase Productive Bacillus tropicus from Fruit and Vegetable Waste Dump Soil
}

\author{
Pitambri Thakur 1 \\ https://orcid.org/0000-0001-7470-8093
}

\author{
Abhishek Kumar Singh ${ }^{2}$ \\ https://orcid.org/0000-0002-4523-6055

\section{Gunjan Mukherjee ${ }^{1^{*}}$} \\ https://orcid.org/0000-0003-2835-9317
}

\begin{abstract}
${ }^{1}$ Chandigarh University, University Institute of Biotechnology, Mohali, Punjab, India; ${ }^{2}$ Chandigarh University, University Institutes of Engineering, Department of Biotechnology Engineering, Mohali, Punjab, India.
\end{abstract}

Editor-in-Chief: Paulo Vitor Farago

Associate Editor: Ana Cláudia Barana

Received: 2020.05.24; Accepted: 2020.12.18.

*Corresponding authors: gunjanmukherjee@gmail.com; Tel.: +91 8054640694 (G. M.).

\section{HIGHLIGHTS}

- Alkaline pectinase is very significant commercial enzyme used in bioscouring process.

- In traditional scouring, textile industry utilizes harmful alkaline chemicals to expel non-cellulosic material from the fabrics.

- Alkaline pectinase productive Bacillus tropicus was isolated from fruit and vegetable waste dump soil.

- Bacillus tropicus characterized by 165 rDNA sequences analysis.

Abstract: Alkaline pectinase is the utmost significant industrial enzyme of the bioscouring process. By considering bio scouring of cotton, 30 microbial isolates from fruit and vegetable waste rich dump soil of Solang Valley and Vasishta (Manali, Himachal Pradesh, India) were isolated and screened for the alkaline pectinase production in the current research work. Only four isolates P3, P16, P21, and P27 were capable to produce extracellular alkaline pectinase at $\mathrm{pH}$ 9. Further by applying submerged fermentation, the alkaline pectinase production was quantitatively screened. The most efficient isolate was P3 identified as Bacillus tropicus, based on morphological, biochemical, and molecular characterization. Molecular characteristics confirmed by 16S rDNA sequence analysis. The nucleotide sequence of the isolate was novel with a $97 \%$ similarity index and submitted to the GenBank with accession number MK332379. The Bacillus strain selected was active at broad pH range from 8-10.5 and a temperature range from $25-50{ }^{\circ} \mathrm{C}$. 
Optimum $\mathrm{pH}$ and temperature observed were 9 and $37^{\circ} \mathrm{C}$ respectively and can be suitably used for the bio scouring process for the pretreatment of the fabrics.

Keywords: Alkaline Pectinase; Bacillus tropicus; Bioscouring; vegetable waste; submerged fermentation.

\section{INTRODUCTION}

Pectinase is a group of one of the commercially important enzymes degrading pectin present in the plant cell wall. Pectinases degrade polysaccharide pectin to monogalacturonic acids and based on activity seven different classes of pectinases are pectinesterase (EC3.1.1.11), polygalcturonase (EC3.2.1.15), galacturan 1, 4- $\alpha$-galactouronidase (EC3.2.1.67), exopoly- $\alpha$-galactouronosidase (EC3.2.1.82), endopectate lyase (EC4.2.2.2), exopectate lyase (EC 4.2.2.9) and endopectin lyase (EC4.2.2.10) [1].

Pectic substances are complex polysaccharides with a (1-4) linkage in galacturonic acid backbone present as a cementing material in the middle lamella and the primary cell wall of all the plants [2,3]. Depending upon the different sources of the plant materials concentration of the pectic substances varies [4]. Commercial pectins are almost exclusively derived from the citrus peel or apple pomace, both byproducts from juice manufacturing. Apple pomace contains $10-15 \%$ of pectin on a dry matter basis and citrus peel contains $20-30 \%[5,6]$.

Industrial enzyme's global market is growing day by day and in the world market, the pectinases production accounts for about $10 \%$ of the total enzyme production. By 2021 the market is estimated to reach around 35.5 million dollars [7]. In altering enzyme properties $\mathrm{pH}$ has a definite role. Acidic pectinases find a wide range of applications in the fruit processing industry for fruit juice clarification [8] and liquefaction of fruit juices [9] while alkaline pectinases find applications in various industrial processes such as fabric, pulp, and paper industry [10].

Alkaline pectinase is an emerging enzyme of commerce with primary employment in the textile and paper industries. Microorganisms are the main source of enzymes due to usage of low-cost substrates [11]. The textile industry is the utmost polluting industry due to maximum chemical usage. Traditional scouring involves alkaline chemicals to expel non-cellulosic material for soft and hydrophilic fiber, suitable for industrial applications. Due to the usage of the alkaline chemicals textile industries releases wastewater with high values of total dissolved solids, chemical oxygen demand, and biological oxygen demand [12-13]. Thus, need of the hour for sustainable development is the replacement of chemical processes to ecofriendly biochemical processes. Bioscouring employs enzymes to remove impurities without disturbing fiber's structure, strength, and environment [14-15].

Due to cheap production, easier gene manipulations, and faster product recovery, microbially derived pectinases find more use due to their advantage over a plant and animal-derived pectinases. The main microbial sources of pectinolytic enzymes are yeast [16], bacteria [17-18] and large varieties of fungi and particularly Aspergillus species [18-19]. Bacteria with well-characterized biology are well exploited as a source of industrially important enzymes. Bacterial pectinases are majorly extracellular enzymes with wide applications in bleaching of papers, wastewater treatment, and coffee fermentation [20-23]. One of the largest genera Bacillus from Firmicutes family covers a great diversity of strains. Bacillus is endosporeforming, gram-positive, rod shape motile bacteria; some are aerobes or facultative anaerobes. Spores are formed under the adverse condition of nutrition or temperature or both. Low cost production with new microbial isolates is fascinating the attention of many researchers nowadays [24]. According to Rehman and coauthors [25] alkaline pectinase produced by Bacillus licheniformis can be used for vegetables and food processing industries effluent treatment and used for bleaching of paper, textile industry for degumming of fiber and protoplast isolation [26]. Alkaline pectinase improves viscosity, breaking length, and porosity of the pulp [27-29]. It also reduces scouring chemicals in the scouring of plant fibers. According to Beg and coauthors [30] alkaline pectinase production is still underdeveloped as very fewer reports are available. According to Pilar and coauthors [31], common agro-industrial substrates such as wheat bran, sugarcane bagasse, rice bran, wheat straw, rice straw, corn cobs, sawdust, coconut coir pith, banana waste, tea waste, sugar beet pulp, apple pomace, orange peel, etc. are employed for pectinase production.

The present study deals with the isolation of the distinct bacterial strains from various sources and further screened for the maximum alkaline pectinase generation and strain identified by conventional and molecular methods. Fruits and vegetable waste rich soil of Solang Valley and Vasishta (Manali, Himachal Pradesh, India) is recycled to produce the alkaline pectinase. They are today one of the upcoming enzymes 
of the commercial sector. It has been estimated that microbial pectinases account for $25 \%$ of the global market. Very few reports are available on the production of alkaline pectinases from Bacillus tropicus.

\section{MATERIAL AND METHODS}

\section{Isolation of bacteria}

The bacteria were isolated from soil collected from nearby fruit and vegetable waste dump in Solang Valley and Vashisht (Manali, Himachal Pradesh, India, Lattitude: $32.2396^{\circ} \mathrm{N}$ and Longitude: $76.9787^{\circ} \mathrm{E}$ ). One gram of soil sample was mixed in $100 \mathrm{~mL}$ of sterile distilled water, afterward serially diluted up to 10 dilutions. A volume of $100 \mu \mathrm{L}$ of each diluted sample was inoculated in pectin agar medium (Sigma Chemical Co.,USA) and incubated at $37^{\circ} \mathrm{C}$ for $48 \mathrm{~h}$ with $\mathrm{pH}$ range from 8 to 10 . The isolated colonies were selected from dilutions $10^{-6}, 10^{-7}, 10^{-8}$, and $10^{-9}$ to obtain pure bacterial cultures. The obtained pure colonies were subcultured in pectin agar medium (Sigma Chemical Co., USA) for further studies and again tested for their potential to use pectin as a growth substrate and cultures maintained in nutrient agar slants.

\section{Screening of alkaline pectinase producing bacteria}

The colonies on the serial dilution plates of $10^{-6}, 10^{-7}, 10^{-8}$, and $10^{-9}$ were transferred on to another pectin agar plates and incubated at $37^{\circ} \mathrm{C}$ for $24 \mathrm{hrs}$ again. Enzyme activity was detected by a clear zone around the colony with the potassium-iodide solution (Merck Ltd., India) [32]. Pectin agar medium described by Soares and coauthors [33] was selected for pure bacterial isolation and composed of citrus pectin $(1.0 \%)$, ammonium sulfate $(0.14 \%)$, di-potassium hydrogen phosphate $(0.6 \%)$, magnesium sulfate $(0.01 \%)$, potassium dihydrogen phosphate $(0.20 \%)$, agar-agar $(2.0 \%)$ and $\mathrm{pH}$ set was 9.0 (Sigma Chemical Co., USA).

Employing submerged fermentation bacterial strain showing the zone of hydrolysis on pectin agar medium were screened using above mentioned broth medium (Sigma Chemical Co., USA). 20\% (v/v) pure cultures inoculums was incubated at $37{ }^{\circ} \mathrm{C}$ for $24 \mathrm{hrs}$. After $24 \mathrm{hrs}$ inoculation transfer into $100 \mathrm{ml}$ fermentation medium and again incubated for $24 \mathrm{hrs}$ at $37^{\circ} \mathrm{C}$. After $24 \mathrm{hrs}$ incubation was centrifuged at $8,000 \mathrm{rpm}$ for $10 \mathrm{~min}$ for biomass separation. The cell biomass obtained from $1.0 \mathrm{~mL}$ culture was washed with $0.01 \mathrm{M}$ Tris- $\mathrm{HCl}$ buffer $(\mathrm{pH}$ 9.0). By sonication cells were lysed and cell debris was removed by centrifugation at $1800 \mathrm{rpm}$ for 15 minutes. The supernatant was checked for pectinase activity.

\section{Molecular Characterization of alkaline pectinase producing bacterial strain}

For the molecular characterization of the selected strain, 16S rDNA sequence analysis was executed. Chen and Kuo [34] method with small changes was used for obtaining genomic DNA. $1.0 \%$ agarose gel electrophoresis was performed for confirmation of the extracted DNA. Then after visualizing under UV light, PCR amplification was performed along with 16S rDNA sequence analysis [35]. 50 microliters of the reaction mixture were prepared to contain dNTPs mix, 2.5 microliters genomic DNA template, 1.0 microliter of $10 \mathrm{pM}$ primers, and 2.5U of DNA polymerase. Gene Amp PCR System 2700 Applied Biosystems was used for the amplification of the genomic DNA. 1.0\% agarose gel electrophoresis was used for the PCR amplified production analysis. After visualizing under UV light, the purification of the PCR amplified product was performed according to the instructional protocol by manufacturer Promega. Amplified DNA fragment sequence analysis performed using 3130 Genetic Analyzer by Applied Biosystem DNA sequencer. MEGA 7 software was used for the phylogenetic and molecular evolutionary genetic analysis [36].

\section{Production and separation of alkaline pectinase protein}

The growth was developed on characterized fluid media as depicted by Bhardwaj [37] containing $1 \%$ unadulterated Pectin (Sigma Chemical Co., USA), $0.1 \%\left(\mathrm{NH}_{4}\right) 2 \mathrm{SO}_{4}, 0.6 \% \mathrm{~K}_{2} \mathrm{HPO}_{4}, 0.2 \% \mathrm{KH}_{2} \mathrm{PO}_{4}$, $\mathrm{MgSO}_{4} \cdot 7 \mathrm{H}_{2} \mathrm{O}, \mathrm{pH} 6.0$ and incubated at $37^{\circ} \mathrm{C}$. Cell debris was expelled by utilizing filter paper. The filtrate was blended in with super cold acetone and permitted to stand $15 \mathrm{~min}$ at low temperature [38]. The whole substance was centrifuged at $6000 \mathrm{rpm}$ for $10 \mathrm{~min}$. The supernatant was disposed of. The precipitate was disintegrated in the least volume of ammonium hydroxide derived buffer $(0.1 \mathrm{M}, \mathrm{pH} 9.2)$ and further exposed to Sephadex G-75 (Pharmacia Fine Chemicals, Sweden) with specific modifications. The purity and molecular weight were determined by SDS PAGE. 


\section{Enzyme assay}

The 3,5-dinitrosalicylic acid (DNS) method given by Miller [39] with slight modifications was employed for the determination of partially purified alkaline pectinase activity by the measurement of the amount of galacturonic acid production. The reaction mixture was incubated at $37^{\circ} \mathrm{C}$ for 10 minutes. In this experiment, the standard graph was prepared by using mono-D-galacturonic acid, and $1.0 \%$ citrus pectin (Sigma Chemical Co., USA) was used as a substrate.

\section{Quantitative Assay of Protein Estimation}

The concentration of total protein in the enzyme sample was estimated by Lowry's method using bovine serum albumin (Sisco Research Laboratories Pvt. Ltd., India) as a standard [40].

\section{Characterization of the partially purified alkaline pectinase}

Partially purified alkaline pectinase was used for the characterization of the alkaline pectinase. To determine the optimum temperature of alkaline pectinase, purified enzyme in the presence of $1 \%$ pectin in sodium borate buffer $\left(\mathrm{pH}\right.$ 9.2) was incubated at a temperature range from $25-50{ }^{\circ} \mathrm{C}$. And $\mathrm{pH}$ effect was studied by carrying reaction in the presence of $1 \%$ pectin (Sigma Chemical Co., USA) in a range of buffer systems such as sodium phosphate (7.2-8.2) buffer and sodium borate (9.2-10.2) buffer (Merck Ltd., India) at $37^{\circ} \mathrm{C}$ for 10 minutes. Similarly, the effect of the substrate concentration was studied by considering 0.5 $3 \%$ substrate concentration in the reaction mixture. Finally, incubation time effect determination was done by employing sodium borate buffer $\mathrm{pH} 9.2$, at $37^{\circ} \mathrm{C}$ in the presence on $1 \%$ pectin for the period range from 24-120 hr with the intervals of $24 \mathrm{hr}$.

\section{Growth media effect on the alkaline pectinase production}

The growth of the isolated bacterial strain was studied using different production media such as malt extract, Nutrient Broth, yeast extract media, Mueller Hinton Broth, Luria-Bertani Broth (Hi Media Laboratories Pvt Ltd., India) culture in fermenter (Scigenics Pvt. Ltd, India) at $37^{\circ} \mathrm{C}$ for $24 \mathrm{hrs}$.

\section{Alkaline pectinase production kinetics:}

The kinetics of alkaline pectinase production was based on the Luedeking-Piret model, initially the growth of the bacterial strain using different production media [41]. This is an unstructured model, which combines to both the growth associated and non-growth associated contribution for pectinase production. Hence, the pectinase production depends upon the bacterial growth rate and biomass concentration can be written as follows:

$$
\frac{d P}{d t}=\alpha \frac{d X}{d t}+\beta X
$$

Where $\alpha$ is growth-associated formation constant of pectinase $(\mathrm{U} / \mathrm{g}), \beta$ is non-growth-associated formation constant of pectinase $(\mathrm{U} / \mathrm{g}), P$ is the pectinase concentration $(\mathrm{g} / \mathrm{L}), P$ is the pectinase concentration $(\mathrm{U} / \mathrm{g})$ and $\mathrm{t}$ is time $(\mathrm{h})$.

\section{RESULTS AND DISCUSSION}

\section{Isolation and screening of alkaline pectinase producing bacterial strain}

Thirty different bacteria were isolated from the soil for primarily screened based on pectinolytic activity by using the spread plate method. Out of these 30 strains, 1- 3 were from cauliflower, $4-7$ were from apple waste, 8-12 was from citrus fruit and $12-30$ were from soil samples. Three isolates (P3, P16, and P27) were found in pectinolytic activity (Figure 1). The positive strain was selected based on the largest hydrolysis zone around its colony in the potassium-iodide assay and evaluate to the other strains. Among them, P-3 isolate showed the largest hydrolysis zone and thus selected for the production, and studies were continued with this strain. 
Table 1. Bacterial isolates from domestic and natural sources

\begin{tabular}{|c|c|}
\hline Bacterial Isolates & Domestic and natural sources \\
\hline $\mathrm{P} 1$ & Cauliflower waste \\
\hline $\mathrm{P} 2$ & Cauliflower waste \\
\hline P3 & Cauliflower waste \\
\hline $\mathrm{P} 4$ & Apple waste \\
\hline P5 & Apple waste \\
\hline P6 & Apple waste \\
\hline P7 & Apple waste \\
\hline P8 & Citrus fruit waste \\
\hline P9 & Citrus fruit waste \\
\hline P10 & Citrus fruit waste \\
\hline P11 & Citrus fruit waste \\
\hline P12 & Citrus fruit waste \\
\hline P13 & Soil sample from Vashisht Kund \\
\hline P14 & Soil sample from Vashisht Kund \\
\hline P15 & Soil sample from Vashisht Kund \\
\hline P16 & Soil sample from Vashisht Kund \\
\hline $\mathrm{P} 17$ & Soil sample from Vashisht Kund \\
\hline P18 & Soil sample from Vashisht Kund \\
\hline P19 & Soil sample from Solang Valley \\
\hline $\mathrm{P} 20$ & Soil sample from Solang Valley \\
\hline $\mathrm{P} 21$ & Soil sample from Solang Valley \\
\hline $\mathrm{P} 22$ & Soil sample from Solang Valley \\
\hline $\mathrm{P} 23$ & Soil sample from Solang Valley \\
\hline P24 & Soil sample from Solang Valley \\
\hline P25 & Soil sample from Solang Valley \\
\hline P26 & Soil sample from Solang Valley \\
\hline P27 & Soil sample from Solang Valley \\
\hline P28 & Soil sample from Solang Valley \\
\hline P29 & Soil sample from Solang Valley \\
\hline P30 & Soil sample from Solang Valley \\
\hline
\end{tabular}




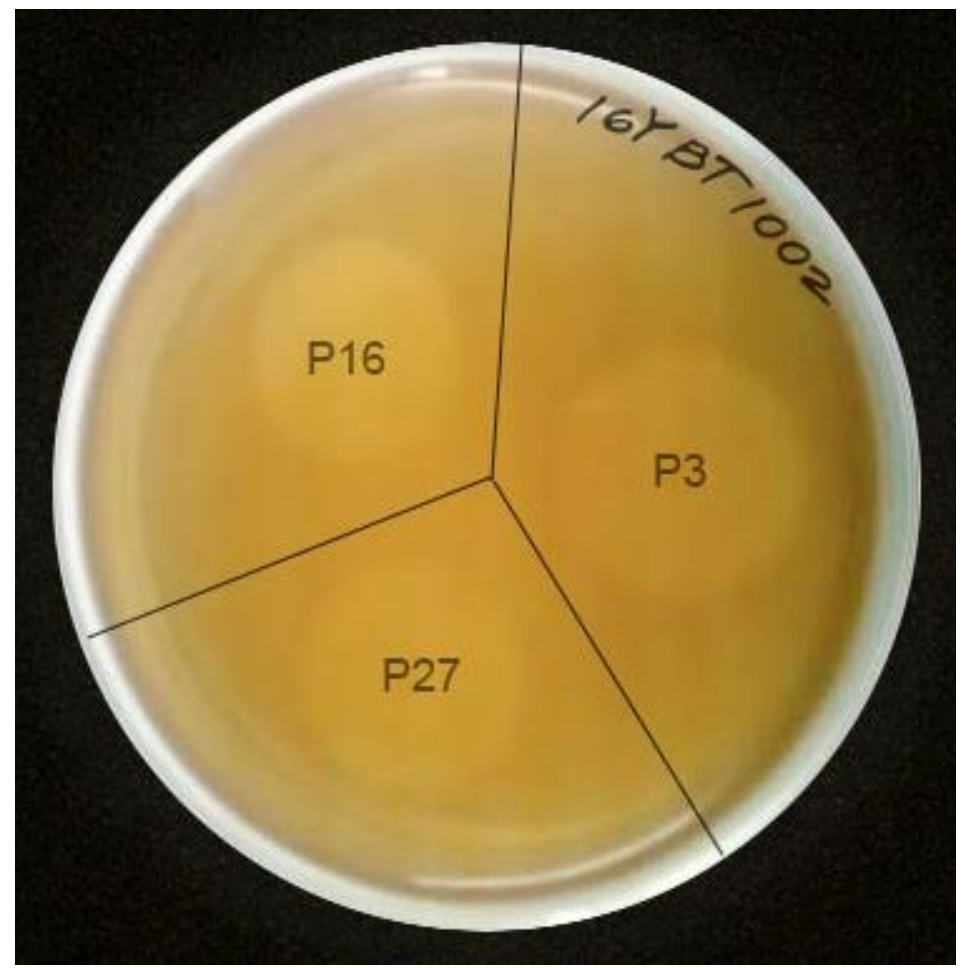

Figure 1. Pectin agar plate showing alkaline pectinase producing bacterial isolate stored after the qualitative screening

For the identification of the selected P-3 isolate the two conventional microbiological and current molecular technologies were used. The selected isolate based on the observed morphological and biochemical characterization (Table 2) compared with Bergey's [42] Manual of determinative bacteriology standard characterization, the isolate P-3 temporarily identified as Bacillus sp. [43].

Table 2. Characteristics of the potent alkaline pectinase producing isolate

\begin{tabular}{ll}
\hline Colony Morphology & Opaque, dull, finally wrinkled and adherent colonies \\
\hline Cellular Characteristics & Positive \\
Gram's staining & Motile \\
Motility & Rods with rounded ends \\
Morphology & $0.5-1.0 \mu m$ in length \\
Size & \\
Biochemical Reactions & +++++ \\
Amylase & +++++ \\
Oxidase & +++++ \\
Catalase & ------- \\
Indole production & +++++ \\
Voges-Proskauer & ------- \\
Citrate utilization & ------- \\
Urea & ------- \\
H2S production & \\
Fermentation Reaction & Acid production \\
Glucose & Acid production \\
Galactose & Acid production \\
Maltose &
\end{tabular}


Isolate's genomic DNA was employed as a template for 16S rDNA amplification by PCR and agarose gel electrophoresis was performed for the examination of the PCR product (Figure 2). The PCR product was first purified to receive the correct sequence and sequenced. To GenBank database 16S rDNA nucleotide sequence was submitted with accession number MK332379 (Figure 3).

A

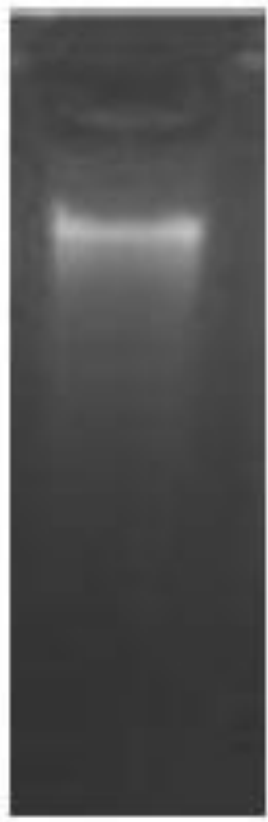

B

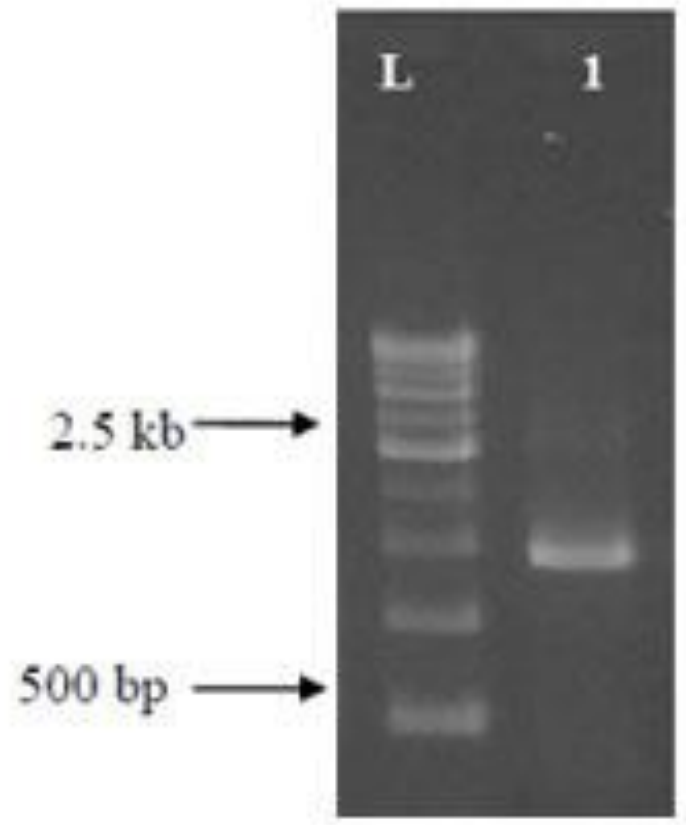

Figure 2. (A) DNA obtained from Bacillus tropicus strain MCCC 1 A01406 (B) Bacillus tropicus 16S rDNA PCR product in agarose gel electrophoresis

1 tgctcttatg agttagcggc ggagggtgag taacacgtgg gtaacctgcc cataagactg

61 ggataactcc gggaaaccgg ggctaatacc ggataacatt ttgaaccgca tggttcgaaa

121 ttgaaaggcg gcttcggctg tcacttatgg atggacccgc gtcgcattag ctagttggtg

181 aggtaacggc tcaccaaggc aacgatgcgt agccgacctg agagggtgat cggccacact

241 gggactgaga cacggcccag actcctacgg gaggcagcag tagggaatct tccgcaatgg

301 acgaaagtct gacggagcaa cgccgcgtga gtgatgaagg ctttcgggtc gtaaaactct

361 gttgttaggg aagaacaagt gctagttgaa taagctggca ccttgacggt acctaaccag

421 aaagccacgg ctaactacgt gccagcagcc gcggtaatac gtaggtggca agcgttgtcc

481 ggaattattg ggcgtaaagc gcgcgcaggt ggtttcttaa gtctgatgtg aaagcccccg

541 gctcaaccgt ggagggtcat tggaaactgg gggacttgag tgcagaagag gagagtggaa

601 ttccatgtgt agcggtgaaa tgcgtagaga tgtggaggaa caccagtggc gaaggcgact

661 ttctggtctg taactgacgc tgaggcgega aagcgtgggg agcgaacagg attagatacc

721 cttgggtagt ccacgccgta aacgatgagt gctaagtgtt agagggtttc cgccctttag

781 tgctgcagtt aacgcattaa gcactccgcc tggggagtac ggtcgcaaga ctgaaactca

841 aaggaattga cgggggcccg cacaagcggt ggagcatgtg gtttaattcg aagcaacgcg

901 aagaacctta ccaggtcttg acatcctctg acaaccctag agatagggct tccccttcgg

961 gggcagagtg acaggtggtg catggttgtc gtcagctcgt gtcgtgagat gttgggttaa

1021 gtcccgcaac gagcgcaacc cttgatctta gttgccagca ttcagttggg cactctaagg

1081 tgactgccgg tgacaaaccg gaggaaggtg gggatgacgt caaatcatca tgccccttat

1141 gacctgggct acacacgtgc tacaatgggc agaacaaagg gcagcgaagc cgcgaggcta

1201 agccaatccc acaatctgt tctcagttcg gatcgcagtc tgcaactcga ctgcgtgaag

1261 ctggaatcgc tagtaatcgc

Figure 3. 16S rDNA nucleotide sequence of Bacillus tropicus 1A01406 
In the NCBI database, BLAST showed significant alignment of Bacillus tropicus with $97 \%$ similarities. And finally, the phylogenetic tree determined the isolate is Bacillus tropicus (Figure 4) [44].

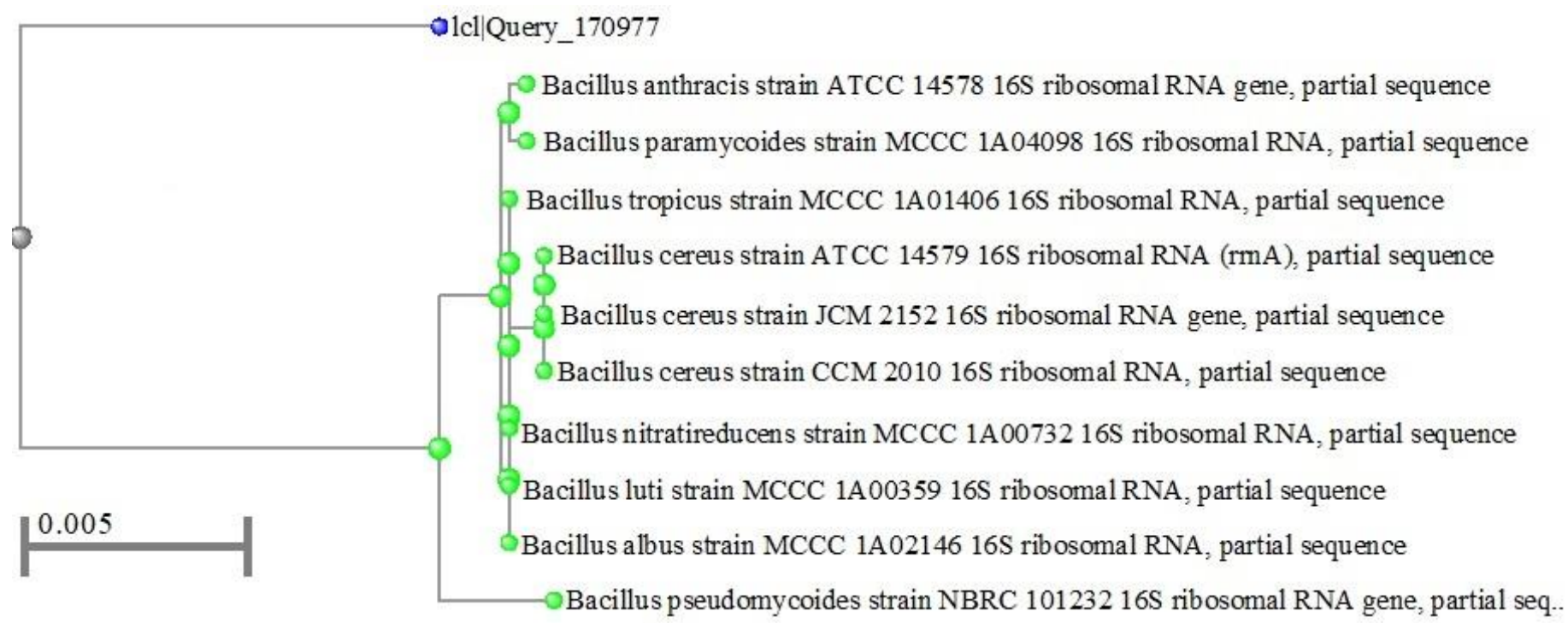

Figure 4. Phylogenetic tree exhibiting the lineage of Bacillus tropicus MCCC $1 \mathrm{~A} 01406$ with another species

\section{Pectinase Activity}

The pectinase activity of Bacillus sp. was evaluated after purification steps. The enzyme unit was defined that the amount of enzyme required to synthesis one $\mu \mathrm{mol}$ of product per minute under standard assay conditions. The alkaline pectinase activity of isolate P-3, P-16, and P-27 were obtained 31.5, 5.25, and $10.02 \mathrm{U} / \mathrm{mg}$ respectively at $37^{\circ} \mathrm{C}$ for $24 \mathrm{hrs}$. The maximum pectinase activity was found by isolate P-3. The present result is supported by the reports of Kashyap and coauthors [45] where they have reported maximum activity $15.4 \mathrm{U} / \mathrm{ml}$ in YEP medium.

\section{Effect of growth media:}

Different media such as Malt extract, Nutrient Broth, yeast extract media, Mueller Hinton Broth, LuriaBertani Broth were used to determine optimum media for alkaline pectinase production. Bacterial isolate was inoculated into $50 \mathrm{~mL}$ of these broths. The maximum growth was observed in Yeast Extract media supplemented with pectin proved to be the finest for the alkaline pectinase production under shaking condition about $43 \mathrm{U} / \mathrm{mL}$ of alkaline pectinase was produced while the alkaline pectinase production was minimum in Luria-Bertani Broth (Figure 5). The findings are also supported by the results of Oumer and Abate, they have also received highest pectinase production using yeast extract medium $10.1 \pm 1.44 \mathrm{U} / \mathrm{mL}$ [46]. 


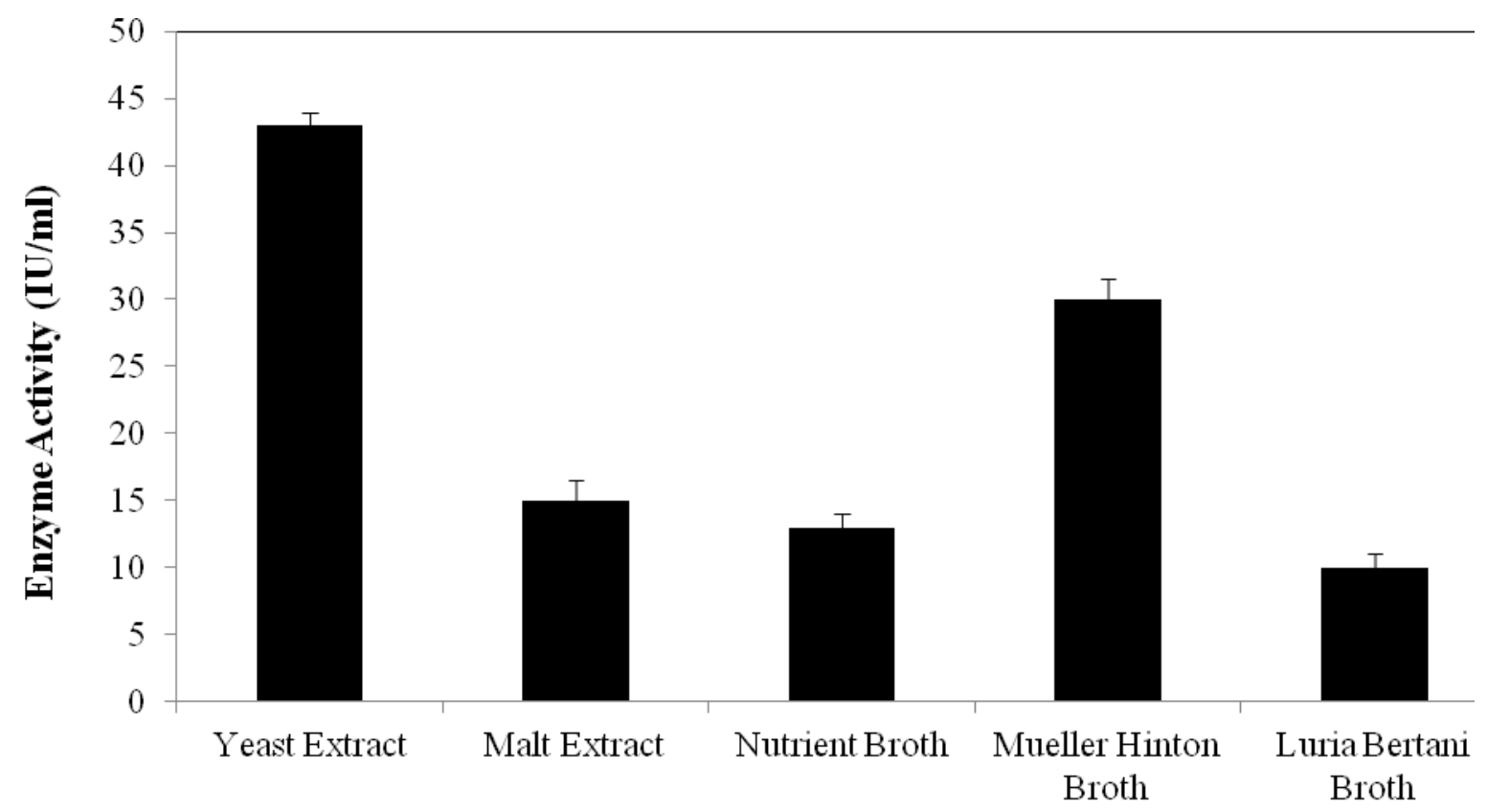

Growth Media (g/L)

Figure 5. Effect of growth media on alkaline pectinase production. Bars correspond to standard deviation.

\section{Production and purification of alkaline pectinase}

The characterized liquid medium was employed for the alkaline pectinase production. From $48 \mathrm{~h}$ old culture the crude enzyme was collected, and acetone precipitated later. After that gel filtration was performed using Sephadex G-75 column chromatography. According to results enzymes were purified 1.4fold with a specific activity of $9.21 \mathrm{U} / \mathrm{mg}$ by using cold acetone purification method and 9.5-fold with the specific activity of $65 \mathrm{U} / \mathrm{mg}$ by using column chromatography. Present results are supported by the findings of Mei and coauthors; they have reported increase in specific activity with the increased purification up to $142 \mathrm{U} / \mathrm{mg}[47]$.

\section{Characterization of alkaline pectinase}

\section{Effect of $\mathrm{pH}$ and temperature}

Factors such as $\mathrm{pH}$ and temperature have a great influence on enzyme activity. In the present study, alkaline pectinase was highly active at $\mathrm{pH}$ range from 7.5-10.5 with the optimum $\mathrm{pH} 9.0$ and confirms the alkaline nature of pectinase (Figure 6). A few previous findings also suggest that the maximum pectinase production from most of the Bacillus spp. is between $\mathrm{pH}$ 7-9 [48]. Similarly, alkaline pectinase activity was found at the temperature range $25-50^{\circ} \mathrm{C}$ with the optimum activity at $37^{\circ} \mathrm{C}$ (Figure 7 ). All the same, Namasivayam and coauthors [49] observed optimum temperature at $37^{\circ} \mathrm{C}$ for maximum pectin production from $B$. cereus. 


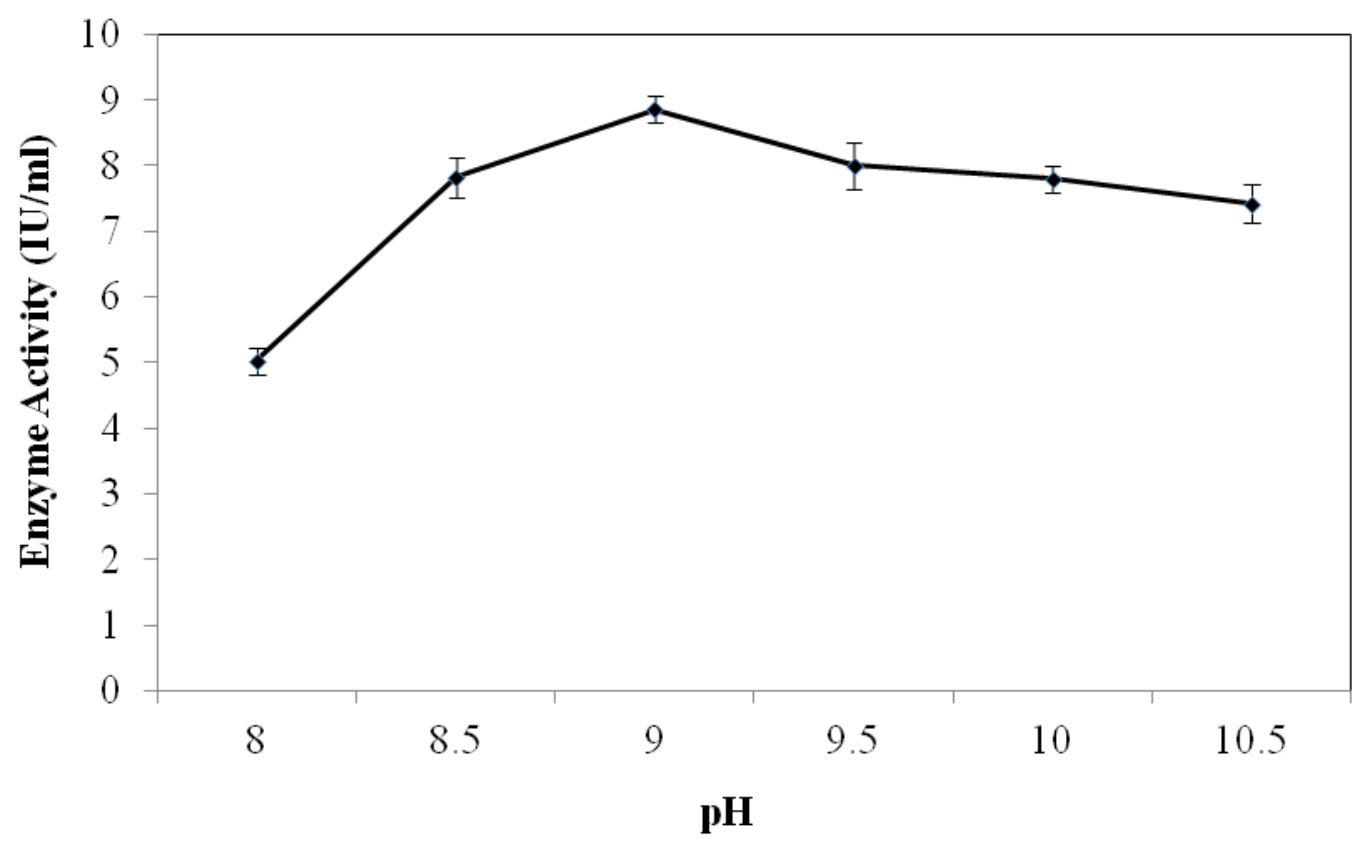

Figure 6. Effect of culture pH on enzyme activity

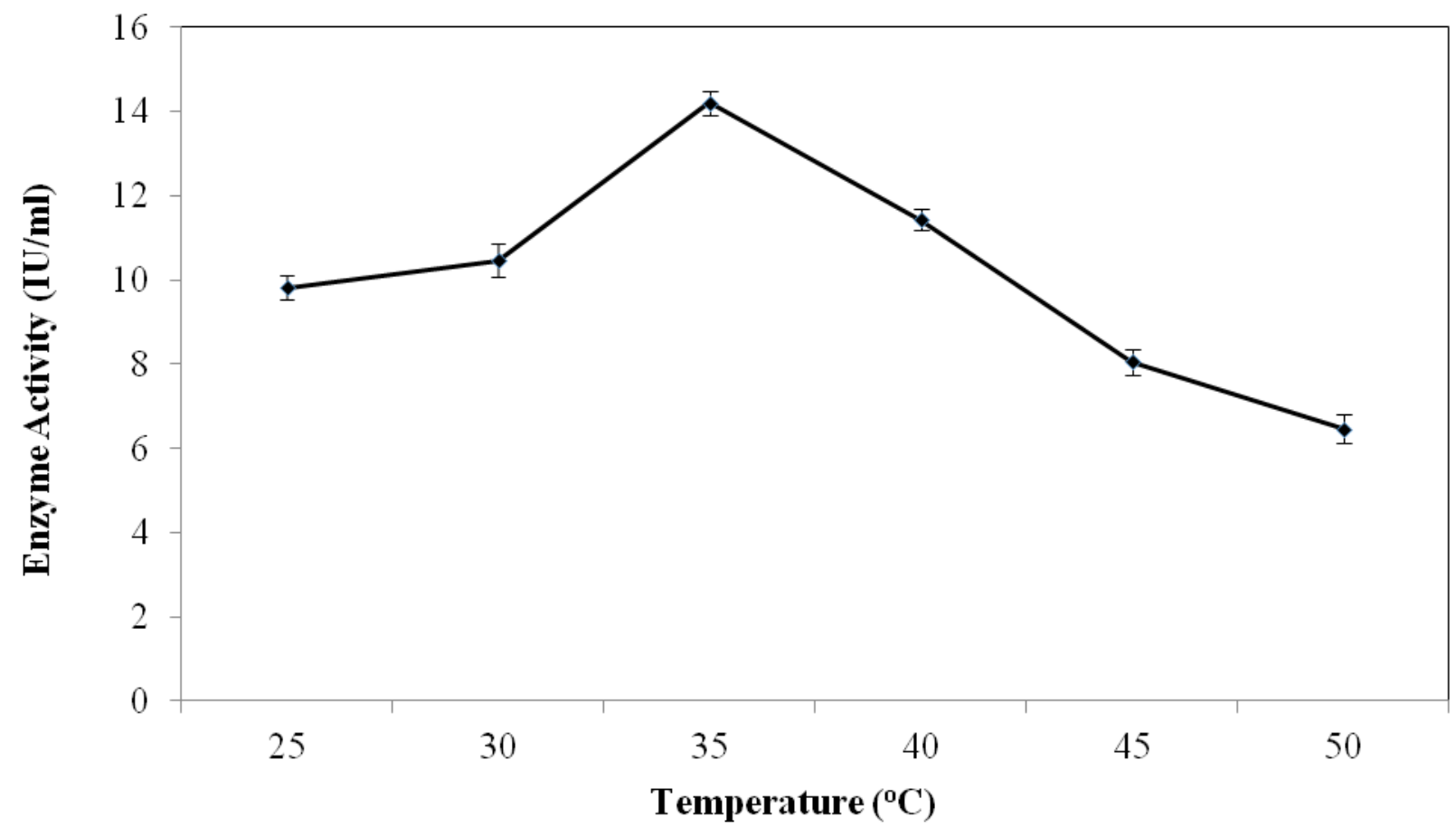

Figure 7. Effect of temperature on enzyme activity

\section{Effect of Incubation time and substrate concentration}

At the $2.5 \%$ pectin concentration, alkaline pectinase showed its maximum activity, with an increase in substrate concentration there was no significant change in alkaline pectinase activity (Figure 8). This finding is also supported by the results of the other study [50]. Same way, the optimum incubation time for alkaline pectinase was observed at $37^{\circ} \mathrm{C}$ for $72 \mathrm{hrs}$ which is like the outcome of Loera and coauthors [51] (Figure 9). 


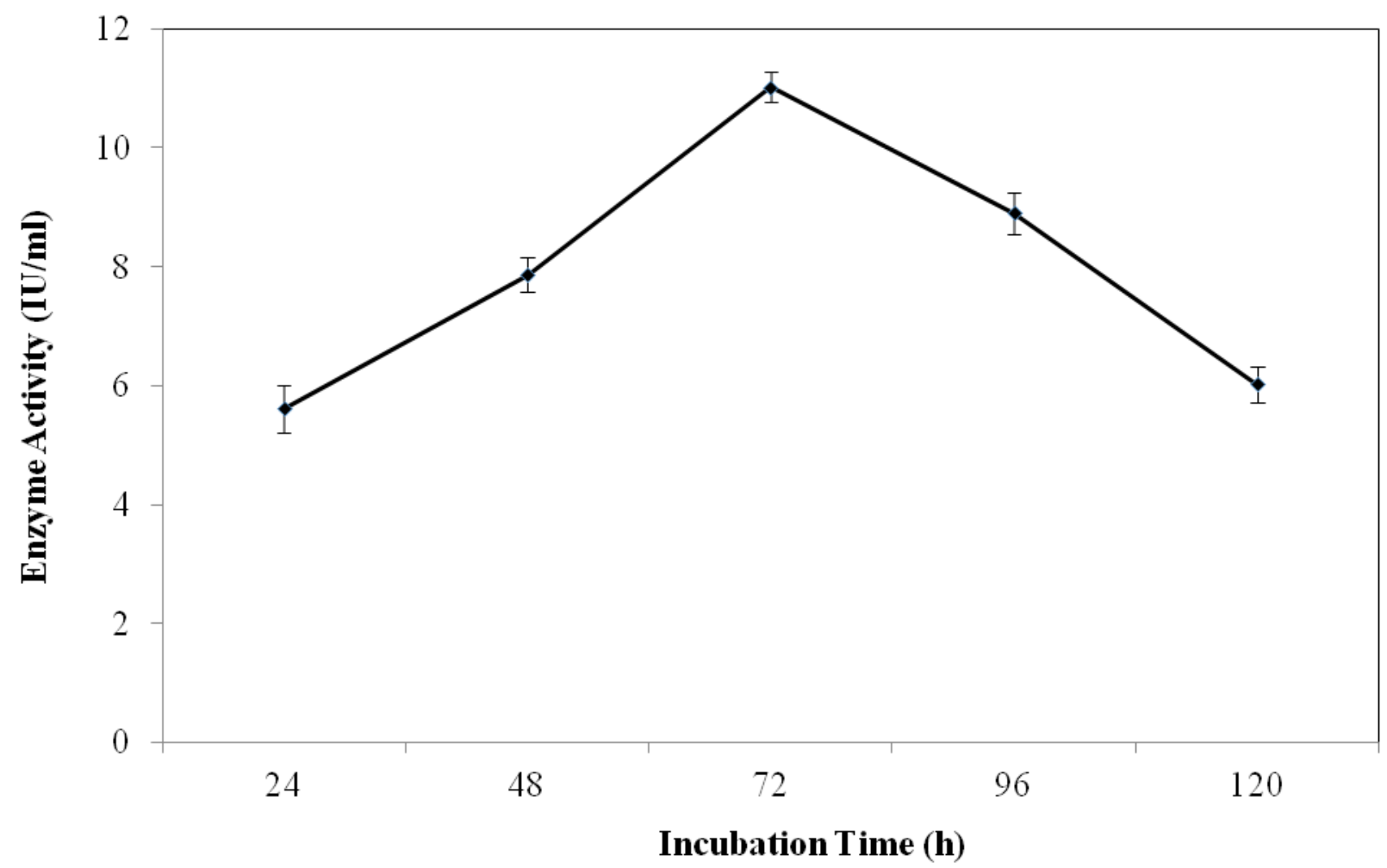

Figure 8. Effect of incubation time on enzyme activity

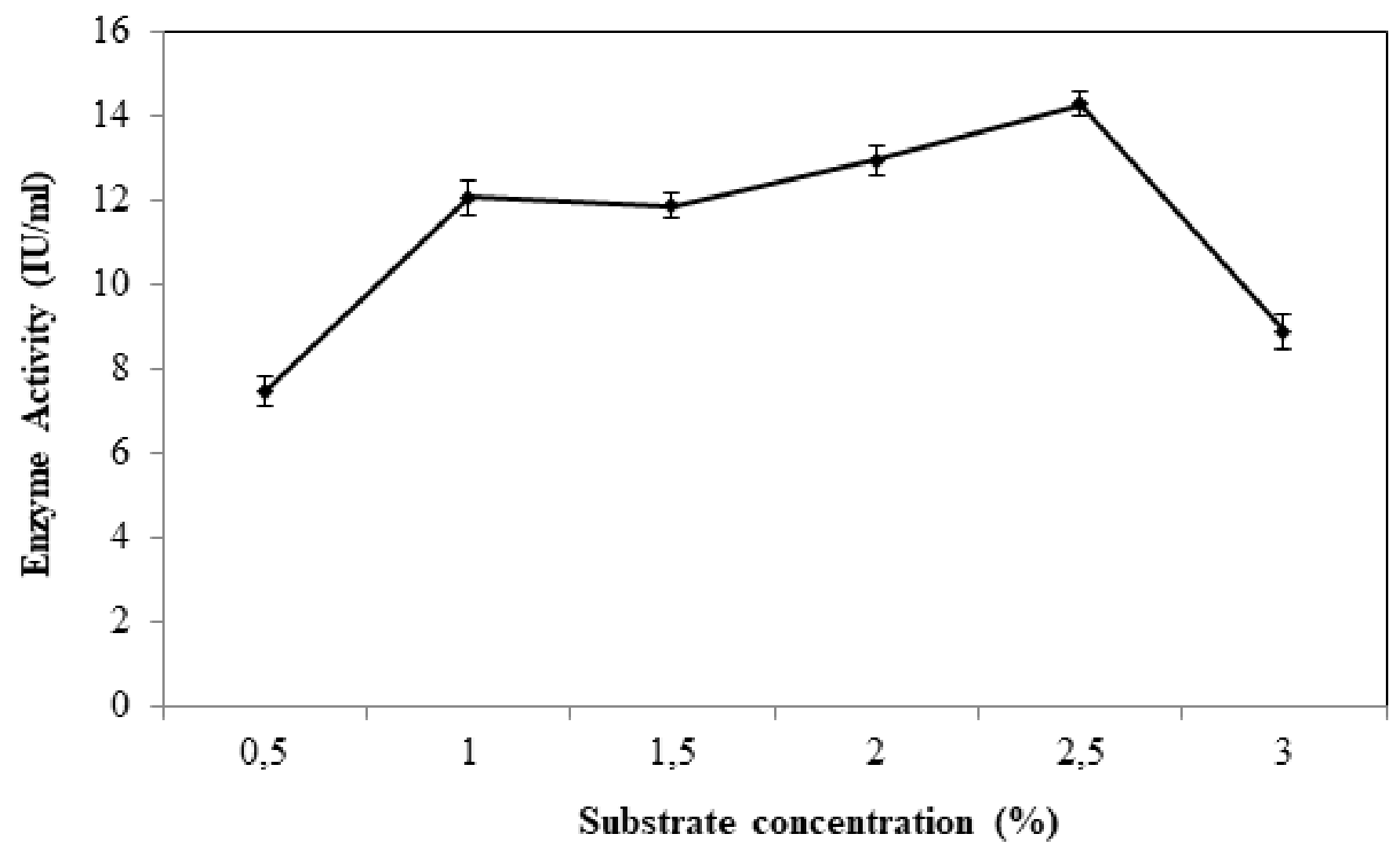

Figure 9. Effect of substrate concentration on enzyme activity 


\section{Enzyme production kinetics}

Alkaline pectinase production kinetics was studies by experiment conditions. The Equation 1 is applied to simulate the production of alkaline pectinase by Bacillus tropicus. The highest concentration of pectinase was produced in $72 \mathrm{~h}(43 \mathrm{U} / \mathrm{mL})$ by experimental results. The pectinase production obtained from the experiments was fitted to the equation under all experimental conditions. The experimental results match with the model predicted values reasonably well with $\mathrm{R}^{2}$ value of 0.90 .

The Michaelis-Menten Kinetics explained the rate of the reaction with respect to the substrate concentration with $\mathrm{K}_{\mathrm{m}}$ and $\mathrm{V}_{\max }$ values of $2.2 \mathrm{gm} / \mathrm{L} \mathrm{mM}$ and $144 \mathrm{U} / \mathrm{mg}$ were determined under standard reaction conditions.

\section{CONCLUSION}

After screening various bacterial isolates to produce alkaline pectinase, only four isolates showed pectinolytic activity. By using the submerged fermentation technique these four isolates were further screened to produce alkaline pectinase. P-3 was observed to produce higher amount of alkaline pectinase. Based on morphological and biochemical characteristics the isolate was identified as Bacillus tropicus. The sequence of the isolated strain was $97 \%$ similar to 16 S rDNA sequences of Bacillus tropicus from different sources of the GenBank database. Yeast extract media supplemented with pectin proved to be the best to produce alkaline pectinase by the isolated bacterial strain. Further to increase its industrial applicability biochemical characterization of alkaline pectinase from Bacillus tropicus MCCC1A01406 will be required. In the present study optimized $\mathrm{pH}$, incubation time, substrate concentration and temperature to produce alkaline pectinase was obtained by using the potential isolate Bacillus tropicus.

Funding: Present research received no external funding.

Conflicts of Interest: The authors declare no conflict of interest.

\section{REFERENCES}

1. Garg A, Singh A, Kaur A, Singh R, Kaur J, Mahajan R. Microbial pectinases: An eco-friendly tool of nature for industries. 3 Biotech. 2016;6:1-13.

2. Amin F, Bhatti HN, Bilal M. Recent advances in the production strategies of microbial pectinases -A review. Int. J. Biol. Macromol. 2019;122:1017-26.

3. Favela-Torress E, Aguilar C, Esquivel-Contreras CJ, Gustavo GV. Pectinase Enzyme technology. Asiatech Publisher Inc. Delhi. 2003;273-6.

4. Jayani RS, Saxena S, Gupta R. Microbial pectinolytic enzymes: a review. Process Biochem 2005;40:2931-44.

5. May CD. Industrial pectins: Sources, production, and applications. Carbohydr. Polym. 1990; 12:79-99.

6. Shet AR, Desai SV, Achappa S. Pectinolytic enzymes: classification, production, purification and applications. Res. J. Life Sci Bioinform Pharm Chem Sci. 2018;4:337 -48.

7. Kavuthodi B, Sebastian D. Review on bacterial production of alkaline pectinase with special emphasis on Bacillus species, Biosci. Biotech. Res. Comm. 2018;11(1):18-30.

8. Tapre AR, Jain RK. Pectinases: Enzymes for fruit processing industry. Int. Food Res J. 2014;21(2):447-53.

9. Kaur G, Sarkar BC, Sharma HK. Production, characterization, and application of a thermostable polygalcturonase of a thermophilic mold Sporotricum thermophile. Bioresour Technol. 2004;94:239-43.

10. Rebello S, Anju M, Aneesh EM, Sindhu R, Binod P, Pandey A. Recent advancements in the production and application of microbial pectinases: An overview. Rev Environ Sci Biotechnol. 2017; 16(3):381-94.

11. Rodrigues PR, Silverio TAB, Druzian JI. Microbial Synthesis and Characterization of Biodegradable Polyester Copolymers from Burkholderia Cepacia and Cupriavidus Necator Strains Using Crude Glycerol as Substrate. Braz Arch Biol Technol. 2019;62:e19170498.

12. Battan B, Dhiman SS, Ahlawat S, Mahajan R, Sharma J. Application of thermostable xylanase of Bacillus pumilus in textile processing. Indian J.Microbiol. 2012;52:222-9.

13. Loow YL, Wu TY, Tan KA, Lim YS, Siow LF, Jahim JM, Mohammad AW, Teoh WH. Recent advances in the application of inorganic salt pretreatment for transforming lignocellulosic biomass into reducing sugars. $J$ Agric Food Chem. 2015;63(38):8349-63.

14. Dutta, AK, Ghosh BL, Aditya RN. The enzymatic softening and upgrading of lignocellulosic fibers: part III: pretreatment of jute with enzymes for fine-yarn spinning. J. Text. Inst. 2000;91:28-34. 
15. Zolriasatein AA, Yazdanshenas ME. Changes in composition, appearance, physical, and dyeing properties of jute yarn after bio-pretreatment with laccase, xylanase, cellulase, and pectinase enzymes. J Text Inst. 2014;105:60919.

16. Martos MA, Zubreski ER, Garro OA, Hours RA. Production of the pectinolytic enzyme by the yeast Wickerhamomyces anomalous isolated from citrus fruit peel. Biotechnol Res Int. 2013; 13:1-7.

17. C. Zhou, Y. Xue, Y. Ma, Cloning, evaluation, and high -level expression of a thermo - alkaline pectate lyase from alkaliphilic Bacillus clausii with potential in ramie degumming, Appl Microbiol Biotechnol. 2017;101:3663-76.

18. Kapoor M, Beg QK, Bhushan B, Dadhich KS, Hoondal GS. Production and partial purification and characterization of a thermo-alkali stable polygalacturonase from Bacillus sp. MG-cp-2. Process Biochem. 2000;36:467-73.

19. Takao M, Nakaniwa T, Yoshikawa K, Terashita T, Sakai T. Purification and characterization of thermostable pectate lyase with protopectinase activity from thermophilic Bacillus sp. TS 47. Biosci Biotechnol Biochem. 2000;64:2360-7.

20. Phutela U, Dhuna, Sandhu S, Chadha BS. Pectinase and polygalacturonase production by a thermophilic Aspergillus fumigatus isolated from decomposting orange peels. Braz J Microbiol. 2005;36:63-9.

21. John J, Kaimal KKS, Smith ML, et al. Advances in upstream and downstream strategies of pectinase bioprocessing: A review, Int J Biol Macromol. 2020;162:1086-99.

22. Patil R, Dayanand A. Exploration of regional agrowastes for the production of pectinase by Aspergillus niger. Food Technol Biotechnol. 2006;44:289-92.

23. Rangarajan V, Ravichandran R. Pectinase production from orange peel extract and dried orange peel solid as substrates using Aspergillus niger. Int J Biotechnol Biochem. 2010;6(3):445-53.

24. Ghazala I, Haddar A, Romdhane MB, Ellouz-Chaanouni S. Screening and molecular identification of new microbial strains for production of enzymes of biotechnological interest. Braz Arch Biol Technol. 2016;59.

25. Rehman HU, Siddique NN, Aman A, Nawaz MA, Baloch AH, Qader SAU. Morphological and molecular-based identification of pectinase producing Bacillus licheniformis from the rotten vegetable. J Genetic Eng Biotechnol. 2015; 13(2):139-44.

26. Power JB, Cocking EC. Isolation of leaf protoplasts: Macromolecule uptake and growth substance response. J Exp Bot. 1970;21(1):64-70.

27. Kaur A, Mahajan R, Singh A, Garg G, Sharma J. Application of cellulose-free xylano-pectinolytic enzymes from the same isolate in bioleaching of kraft pulp. Bioresour Technol. 2010;101:9150-5.

28. Agarwal S, Yadav RD, Mahajan R. Synergistic effect of xylano-pectinolytic enzymes produced by a bacterial isolate in bleaching of plywood industrial waste. J Clean Prod. 2016;118:229-33.

29. Walia A, Guleria S, Mehta P, Chauhan A, Prakash J. Microbial xylanase and their industrial application in pulp and paper biobleaching: a review. 3Biotech. 2017;7(11):2-12.

30. Beg QK, Bhushan B, Kapoor M, Hoondal GS. J Ind Microbiol Biotechnol. 2000;24:396-402.

31. Pilar B, Carman S, Tmaes G. Villa production of pectic enzymes in yeast. Microbiol Lett. 1999;175:1-9.

32. Fernandes-Salomao TM, Amorim ACR, ChavesAlves VM, Coelho JLC, Silva DO, Araujo EF. Isolation of pectinases hyperproducing mutants of Penicillium expansum. Braz J Microbiol. 1996;27:15-8.

33. Soares MMCN, Da Silva R, Carmona EC, Gomes E. Pectinolytic enzyme production by Bacillus species and their potential application of juice extraction. World J Microbiol Biotechnol. 2001;17:79-82.

34. Chen W, Kuo T. A simple and rapid method for the preparation of gram-negative bacterial genomic DNA. Nucleic Acids Res. 1993;21:2260.

35. Ansari A, Aman A, Siddiqui NN, lqbal S, Qader SAU. Pak J Pharm Sci. 2012; 25:195-201.

36. Tamura K, Dudley J, Nei M, Kumar S. MEGA4: Molecular evolutionary genetics analysis (MEGA) software version 4.0. Mol Biol Evol. 2007;24:1596-9.

37. Bhardwaj V. Exploitation of micro-organisms for isolation and screening of pectinase from the environment. In: Globelics 2010 8th International Conference, University of Malaya, Kuala Lumpur, Malaysia, 1-3 November 2010.

38. Rajendran R, Sundaram KS, Radhai R, Rajapriya P, Balakumar C. Production and optimization of fungal pectinase from Fusarium sp. Int J Curren Res. 2011;3(4):254-8.

39. Miller GL. Anal. Chem. Use of Dinitrosalicylic acid reagent for determination of reducing sugar. 1959; 31:426-428.

40. Lowry OH, Roserbrough NJ, Farr AL, Randall RJ. Protein measurement with the Folin phenol reagent. J Biol Chem. 1951;193:265-75.

41. Luedeking R, Piret EL. A kinetic study of the lactic acid fermentation:batch process at controlled Ph. J Biochem Microbiol Technol Eng. 1959;1:393-412. 
42. Holt JG, Krieg NR, Sneath PHA, Staley JT, William ST. Bergey's Manual of Determinative Bacteriology, ninth ed., Williams and Walkins, Baltimore. 1994;787.

43. Felsenstein J. Confidence limits on phylogenies: An approach using the bootstrap, Evolution. 1985; 39: 783-791.

44. Tamura K, Nei M, Kumar S. Prospects for inferring very large phylogenies by using the neighbor-joining method, Proceeding of the National Academy of Sciences (USA). 2004;101:11030-5.

45. Kashyap DR, Chandra S, Kaul A, Tewari R. Production, purification and characterization of pectinase from a Bacillus sp. DT7. World J. Microbiol. Biotechnol. 2000;16:277-82.

46. Oumer OJ, Abate D. Comparative Studies of Pectinase Production by Bacillus subtilis strain Btk 27 in Submerged and Solidstate fermentations, Biomed Res Int. 2018;1514795.

47. Mei Y, Chen Y, Zhai R, Liu Y. Cloning, purification and biochemical properties of a thermostable pectinase from Bacillus halodurans M29, J Mol Catal B Enzym. 2013;94:77-81.

48. Kobayashi T. Purification and properties of a low-molecular-weight, high-alkaline pectatelyase from an alkaliphilic strain of Bacillus, Basic Biotechnol Biochem. 1999;63:65-72.

49. Namasivayam E, John Ravindar D, Mariappan K, Jiji A, Kumar M, Jayaraj RL. Production of extracellular pectinase by Bacillus cereus isolated from market solid waste, J Bioanal Biomed. 2011;3:70-5.

50. Khan IG, Barate DL. Effect of Various Parameters on Activity of Pectinase Enzyme, Int J Adv Res. 2016;4(1):853-62.

51. Loera O, Aguirre J, Viniegra-González G. Pectinase production by a diploid construct from two Aspergillus niger overproducing mutants. Enzyme Microb. Technol. 1999;25(1-2):103-8.

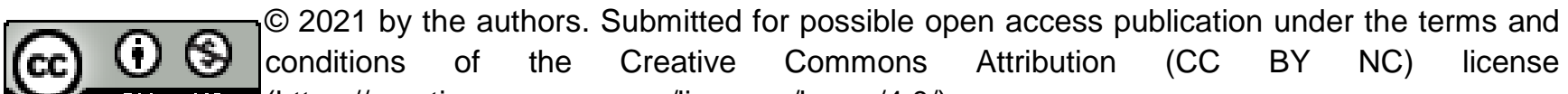
BY NC (https://creativecommons.org/licenses/by-nc/4.0/). 